\title{
Vroue-ervaring en spiritualiteit
}

\author{
Yolanda Dreyer \\ Tydelik-deeltydse dosent: Departement Praktiese Teologie (Afd A) \\ Universiteit van Pretoria
}

\begin{abstract}
:
Women's experience and spirituality

Spiritually concerns one's orientation to the. It therefore influences one's tdentity. This article necognises a plirnity of spirinualities. It focuses on the relation-shp between women's experience and spiritually with the fromework of Christien failh. The concept partiderchaler Bnthending is Iluminated. This is the allenation women experience when they exist as women in mals. defined, male-structured and male-dominated ecclesiastical cultures. As for as "identily" is concened the problem of women's spiritual development and mathity as pre-requisils for an cuthentic life before Coil is discussed.
\end{abstract}

\section{SPIRITUALITEIT EN KONTEKSTUALITEIT}

Spiritualiteit is 'n algemeen menslike verskynsel. Vir die doeleindes van hierdie artikel is ek geïnteresseerd in die verband tussen spiritualiteit en vroue-ervaring ten opsigte van die Christelike geloof. Wat spiritualiteit betref, tree die artikel in gesprek met die werk van Andrea Schulenburg (1993), Feministische Spiritualität: Exodus in einer befreiende Kirche? en dié van Theuns Dreyer (1998), "Spiritualiteit, identiteit en die etos van die Hervormde Kerk". My perspektief op vroue-ervaring en spiritualiteit word aangebied met 'n narratiewe inslag.

Binne die Christelike tradisie is daar verskillende vorme of gestaltes van spiritualiteit (kyk Dreyer 1998:5-7). Spiritualiteit is nie 'n verskynsel wat slegs beperk is tot die charismatiese kringe of tot 'n beklemtoning van mistiek soos dit in die RoomsKatolieke tradisie gevind word nie. Dit kom ook by Christene binne die Reformatoriese kerke voor. Dreyer (1998:6) wys daarop dat selfs in die Reformatoriese tradisie spiritualiteit gekenmerk word deur 'n diversiteit van styl, taal, etnisiteit en geskiedenis. Die verskille wat daar binne dieselfde tradisie bestaan, kan toegeskryf word aan onder 
andere 'n verskil in Skrifbeskouing en aan die verskillende verstaan van die Bybelse boodskap.

In die hedendaagse interpretasie van die Bybel word sterk op kontekstualiteit klem gelê. 'n Mens kan sê dat hierdie klem een van die kenmerke van sowel die laatmoderne as postmoderne Bybeluitleg is. In hierdie verband verskil laasgenoemde van eersgenoemde in onder andere die waarde wat daar aan kontekstualiteit as "totaliteit" geheg word. Andrew Adam (1995:8) verduidelik hierdie verskil in sy boek What is postmodern biblical criticism?:

If we want to understand a text from a distant culture, we can - on a modern account - enter into the text's world on the basis of the humanity we share with the text's original authors and addressees. [That is, considering context.]

"Totalities" do not have to be universal sets of certain kinds of things (or of everything), however, a totality may be restricted to a particular unitary set. Modern thought has established the pivotal importance of a rather smaller totality: the individual, who subsists as a selfcontained totality of experiences, thoughts, feelings, desires, and so on - Modern thinking distinguishes sharply between what is proper to the individual (what you have seen with your own eyes, your own belongings, your skills) and what is imparted or imposed from circumstances beyond the individual -

Postmodern thinkers generally resist such totalities. Totalities, after all, either include everything altogether or proceed by excluding some possible members.

Wat hieruit voortspruit, is dat die begrip "kontekstualiteit" wat in die postmoderne era belangrik geword het, onvermydelik gepaard gaan met die waarde wat daar aan pluraliteit verleen word. Dit beteken dat die konsep "kontekstualiteit" in die post-moderne paradigma krities verreken word. Daarvoor span Theuns Dreyer (1998:7) die begrip "hermeneutiek van suspisie" in. Met so 'n benadering kan die verskillende spiritualiteite verrykend op mekaar inwerk, sonder dat geloofsgemeenskappe die gevaar loop om hulle identiteit te verloor. Hy formuleer die korrelasie tussen spiritualiteit en identiteit soos volg: "Spiritualiteit as lewensoriëntasie is verantwoordelik vir die mens se identiteit ... Spiritualiteit as semantiese struktuurkern is daarom noodsaaklik vir die verstaan van dit wat mense se lewe sin en waarde gee. As betekeniskern van 'n mens se 
lewe het spiritualiteit te doen met 'n religieuse selfpersepsie" (Dreyer 1998:11; vgl ook Schulenburg 1993:41). Identiteit word gevorm deur twee sake: internalisering en identifikasie (Dreyer 1998:11). Identifikasie is nie net 'n individuele aangeleentheid nie maar hou ook met sosiale (o a kerklike) groepering verband. Spiritualiteit het altyd sowel 'n individuele, persoonlike as 'n korporatiewe, gemeenskaplike dimensie. Dreyer (1998:11) praat spesifiek van 'n geloofsgemeenskap as hy aandui dat, wanneer spiritualiteit verval, die gemeenskap in ' $n$ identiteitskrisis beland. Dieselfde sou dan sekerlik geld vir die individu: 'n probleem met die spiritualiteit van die individu sou kon lei tot identiteitsverwarring.

Wat die vorming van spiritualiteit betref, meen Dreyer (1998:18) dat, in 'n tyd van verandering, die aksent moet verskuif van "wat ons glo" na "wie ons is". Dit gaan met ander woorde nie in die eerste plek om ortodoksie nie, maar om die identiteit en karakter wat deur die geloof in God gevorm word. Ortodoksie, soos die etimologiese samestelling van die woord ook sê, is geïnteresseerd in die "regte leer" - met ander woorde in die wat van die geloof en nie soseer in die wie, naamlik die persoon wat glo nie. Die ortodoksie se belang by die persoon wat glo, is hoofsaaklik in terme van haar of sy identiteit as gebroke sondaar wat deur kennis van sonde en die vashou aan die "regte leer", van sonde verlos kan word.

Saam met die filosoof van die Randse Afrikaanse Universiteit, Gideon Rossouw (1993:902), sien Dreyer die proses van identiteitsvorming egter nie slegs as 'n blote intellektuele proses nie, maar as 'n omvattende proses van sosialisering binne 'n gemeenskap van gelowiges. Die lewe binne die geloofsgemeenskap moet dus op so 'n manier ingerig word dat dit ruimte bied vir hierdie proses van sosialisering en karaktervorming. Ook die teologiese opleiding en vorming van predikante moet volgens Dreyer (1998:19) die milieu skep vir so 'n sosialiseringsproses. Daar moet aandag gegee word "aan die vorming van die spiritualiteit en identiteit van die voornemende predikant." Ten opsigte hiervan beklemtoon hy twee sake: "die voorleef van die eie spiritualiteit deur dosente en die pastorale begeleiding van studente in hulle identiteitskrisis ..." (Dreyer 1998:20).

Dreyer (1998:14) verbind sowel die teologie, as beide die spiritualiteit en die identiteit waaraan die teologie geboorte gee, met die "etos" van 'n denominasie. Die etos vind neerslag in bepaalde gebruike en gewoontes. Volgens my behoort die etos van 'n Christelike geloofsgemeenskap só inklusief en kultuurkrities te wees dat kerkwees alle grense van etnisiteit, ouderdom en geslag oorskry. Dreyer toon tereg aan 
dat gebruike en gewoontes as simbole van 'n geloofsgemeenskap se identiteit dien. 'n Identiteitskrisis in die betrokke geloofsgemeenskap word beleef wanneer veranderings in die simboliese universum verskuiwings in die sosiale wêreld meebring. Ek stem met hom saam dat veranderings nie net negatiewe gevolge het in die sin dat dit byvoorbeeld identiteit bedreig nie. Wanneer veranderings doelbewus aangebring word, behoort dit wel goed verantwoord te word. Met die inagneming van die identiteit van 'n geloofsgemeenskap, moet daar altyd krities gesoek word na vorme wat in elke nuwe tyd uitdrukking kan gee aan die gemeenskap se spiritualiteit en identiteit (Dreyer 1998:14). Die teologie van die geloofsgemeenskap neem dus 'n sentrale plek in. Dit is die bron van waaruit die spiritualiteit, identiteit en etos van die geloofsgemeenskap voortvloei. Dreyer (1998:16) sien die teologie van die geloofsgemeenskap nie net as 'n rasionele werksaamheid nie. Dit is 'n geloofswerksaamheid omdat dit van 'n geloofsapriori vertrek, naamlik die "heil van die lewende God in Christus". Daarom meen hy dat die teologie nie net 'n leerkwessie (ortodoksie) is nie, maar 'n lewenskwessie (ortopraksie) .

Aangesien die Nederduitsch Hervormde Kerk en die Reformatoriese tradisie my eie konteks is, is Dreyer se artikel wat hierdie sake in verband bring met spiritualiteit, vir my van belang. 'n Perspektief wat uiteraard vir die doeleindes van hierdie artikel belangrik is, is dié van "vrou". Ek wil vervolgens die drie aspekte met mekaar in gesprek bring, te wete spiritualiteit, teologiese tradisie en vrou. 'n Verhaal sal myns insiens as 'n goeie aanknopingspunt vir die gesprek dien. Dit is die verhaal van die Lutherse teoloog en predikant Bärbel von Wartenberg-Potter (1987:45-46). Sy vertel haar verhaal in die derde persoon.

It all started during her theological studies, when she discovered that at no point was there a woman at the ceritre of academic attention ... There were very few examples of independent women from whom she could have taken her cue. She assumed the expected male manners. She learnt not to talk about personal things, not to take women seriously any longer (with the exception of mothers, of course), to model her thinking and behaviour on the careers and thoughts of famous men. She learnt how to be cool and clear in analyzing issues scientifically and to come to well-balanced choices. Never in her life had she seen a woman minister in the pulpit until she herself entered it for the first time. More and more she adapted herself to the male culture, accepted the style of the men's organizations in which 
she had to function. There they have their own regulations, rituals, manners of speech and thought, ways-of-doing-things, relationships among themselves. They have their own ways of exercising power, hiding aggressions behind questions about points of order and behind brilliant formulations. And so she has had to try and prove that she, too, could do all these things.

It was only the "brethren" who featured in the language of the order of service, the verses of the hymns and in many Bible passages. Women's problems ... were largely alien for "brotherland". They did not fit into its well-ordered framework ... Was she mistaken or not in thinking that the gospel had something to say to these questions? ... A patronizing openness permitted her to bring a quality of human warmth to bear on the sober order of business - through songs, flowers, pictures, small variations in style, through creating a little space for the personal. But she kept asking herself whether this was really all. Was this really all Jesus had in mind when he called people to discipleship? ... The question remains valid: How can she as a woman sing God's song in the "brotherland" of the church? She did not just want to sing about the obvious, the expected, but her own Song of Zion. She did not want to hang her harp on the willows and keep silence - not again.

Die verhaal van Bärbel von Wartenberg-Potter is in 'n verstommende graad van akkuraatheid ook my verhaal, selfs al verskil ons kontekste so ver soos die noordelike halfrond van die suidelike, die Duitse kultuur van die Afrikaanse, en binne die Reformatoriese tradisie die Lutherse van die Hervormde. Dit is 'n verhaal van vervreemding. Von Wartenberg-Potter (1987:43) beskryf vroue wat leef binne 'n kultuur wat deur mans gedefinieer is met 'n beeld uit Psalm 137: "The women sit by the rivers of Babylon, displaced, estranged, full of homesickness, having hung their harps on the willows, having been silenced for centuries. No one took notice of the language of their silence; not even themselves; for women it had become second nature to be silent, a second self ...."

Ten opsigte van vroue en hulle spiritualiteit wil ek vervolgens fokus op die relasie tussen spiritualiteit en vervreemding (soos dit na vore gekom het in die werk van Von Wartenberg-Potter 1987 (vgl ook Schulenburg 1993:17; Bührig 1993) en die relasie tussen spiritualteit en identiteit (soos dit na vore gekom het in die artikel van Dreyer 1998 (vlg ook Conn 1986a; Schulenburg 1993). 


\section{VERVREEMDING}

\subsection{Inleiding}

Vroue se vervreemding van die kerk waarvan die verhaal hierbo getuig, word deur Schulenburg (1993:13) getipeer as "patriarchaler Entfremdung". Dit is die vervreemding wat vroue ervaar wanneer hulle binne 'n manlik gedefinieerde, gestruktureerde en geregeerde kerklike kultuur as vrou en as gelowige probeer lewe. Dit is tragies dat vroue van hulleself vervreem raak wanneer hulle die Christelike tradisie en die Godsbeelde wat daarmee gepaard gaan, onkrities aanvaar (Conn 1986b:10). Schulenburg kies egter ten spyte hiervan bewustelik om nie toe te laat dat hierdie ervaring van vervreemding haar totaal afsny van haar wortels en tradisie nie. Sy wil haar teologie beoefen "in kritischer Solidarität zu meinem christlichen Erbe". Ook Von Wartenburg-Potter (1987:18), wat heelwat maak van die konsep "vervreemding", se titel van die tweede hoofstuk van haar boek is "Declaration of love to the church". Sy beskryf haarself in haar liefde vir die kerk as weerloos, gevul met vertwyfeling en konflikterende gedagtes en gevoelens, maar nogtans baie eg (Von Wartenburg-Potter 1987:19). In aansluiting by hierdie twee Duitse teoloë bevind ek myself ook in kritiese solidariteit met my eie kerk.

Die "Women Church"-beweging in die VSA en die "Vroue en Geloof"-beweging in Nederland (kyk Bons-Storm 1996) getuig egter daarvan dat baie vroue nie die weg van kritiese solidariteit met hulle kerke kies nie, maar uit moedeloosheid en frustrasie met die onveranderlikheid en rigiditeit van die manlike kerk, die kerk verlaat en hulle eie weg vind. Ook die twee Duitse teoloë verwys na die uittog van vroue uit hulle kerke. Von Wartenberg-Potter (1987:19) beskryf dit so: "It is this very church which does not move a finger as it simply stands by and watches the walkout of ... women from its ranks, without recognizing the deeper meaning of and search for the absolutely essential renewal of our male brain-religion:" Suid-Afrika het altyd die voordeel om die tendense in die noordelike halfrond te kan raaksien voordat dit in hierdie land 'n werklikheid word. Die vraag is of die Westers-georiënteerde kerke in Suid-Afrika bereid gaan wees om te luister na die stemme van kerkvroue in ander Westerse lande en betyds ruimte gaan skep vir vroue om outentieke lewe voor God (outentiek in hulle identiteit en spiritualiteit en tuis in hulle geloofsgemeenskap) moontlik te maak. 


\subsection{Die bydrae van Andrea Schulenburg}

Oor die tendense wat te bespeur is by vroue in die kerk in Europa (en wat Westersgeoriënteerde kerke in Suid-Afrika dus binne 'n dekade of so kan verwag) het Schulenburg (1993) navorsing gedoen. Ek maak van die resultate van haar navorsing ebruik om aan te dui hoe vroue die vervreemding beleef en daarop reageer. In haar navorsing het Schulenburg (1993:24-26) bevind dat daar 'n dramatiese afname is in jonger vroue wat die kerk gereeld besoek, van $64 \%$ in 1953 tot $7 \%$ in 1985 . Haar studie het die volgende groepe en standpunte onder die vroue uitgewys:

\section{- Vroue wat tevrede is}

Hierdie groep bestaan meesal uit ouer vroue wat nie probleme het met die kerk of met hulle plek in die kerk nie. Hulle kan hulle heel goed identifiseer met die tradisionele kerklike beeld van die vrou, naamlik die vrou as moeder. Jonger vroue word selde in hierdie groep gevind.

\section{- $\quad$ Kritiese vroue}

In hierdie groep kom vroue van alle ouderdomme voor, maar veral die ouderdomme 35-50 word goed verteenwoordig. Hierdie groep word steeds groter. Dit is vroue wat wel nog lede van die kerk is, maar wat toenemend ontuis begin voel in die kerk. Hulle spreek hulle ontevredenheid uit met die rigiede vorme in die kerk. Ten opsigte van hoe hulle die kerk ervaar, noem hulle die volgende: dat eensydige rolle aan hulle toegeken word (kinders, kombuis en kerk); dat hulle vrae en ervarings nie ernstig opgeneem word nie, en dat hulle toenemend isolasie beleef; dat die manlike kerkleiers se eensydige aanbieding van geloof en moraliteit toenemend uit pas raak met hulle lewenswerklikheid. Een van die kernsake wat verband hou met spiritualiteit, naamlik die behoefte aan betekenis- en singewing, word steeds minder vervul deur wat die kerk voorhou (voorskryf?). Die kerk se pogings tot singewing word beleef as leeg en uitgedien. Die vroue spreek ook hulle ontevredenheid uit met die beeld van "die vrou" in die kerk - dit word ervaar as eng, beperkend en diskriminerend. Die kerk se rigiditeit op die gebied van seksuele moraliteit word ook beleef as totaal uit pas met die werklikheid waarbinne hulle leef. Op hierdie gebied is die kerk nie meer in staat om antwoorde te verskaf op wesenlike bestaansvrae 
van vroue nie. Hierdie navorsingsresultate dui gedurende die laaste dekades op 'n verandering in die selfverstaan van vroue. Baie van hierdie kritiese vroue wil wel graag in die kerk bly omdat hulle meen dat Jesus die boodskap van 'n verlossende, bevrydende God bring en omdat hulle glo dat die kerklike en samelewingspraktyk kan verander (vgl Unterberger 1990:60). Hulle voel egter gefrustreerd met die gebrek aan ruimte om ook vanuit 'n vroue-perspektief ' $n$ bydrae in die kerk te kan lewer.

- Vroue wat die kerk verlaat het

Van die vroue in die vorige groep het moeg geword vir die ewige stryd om ruimte in die kerk, asook vir die kerk se onbeweeglikheid. Teleurgesteld dat hulle steeds soos onmondige mense behandel word, vasgevang in stereotipiese rolle, het hulle die kerk verlaat. 'n Onderdrukkende sosialisering in die kerk lei daartoe dat godsdienstige norme en singewing nie as verlossend en bevrydend beleef word of die ruimte skep waarbinne vroue spirituele kompetensie kan ontwikkel nie. Singewing in die Christelike godsdiens word toenemend as vyandig teenoor die vrou beleef, en word daarmee onaanvaabaar vir hierdie vroue. Vroue wat in botsing kom met rigiede kerklike norme ten opsigte van byvoorbeeld egskeiding en hertrou, saamwoon en die bewuste keuse om nie kinders te hê nie, ervaar dat die kerk ook onmagtig geword het om lewenshulp te bied.

\section{- Die ongeïnteresseerdes}

Ook hierdie groep word steeds groter. Dit bestaan uit vroue wat hulle totaal gedistansieer het van kerk en godsdiens, maar steeds die sogenaamde "Christelike norme" ten opsigte waarvan hulle gesosialiseer is, as relevant beskou. Die "ongeïnteresseerde" staan ook bekend as die "gesekulariseerde" mens.

\section{- Die nuuskieriges}

In die studie is ' $n$ nuwe groep geidentifiseer. Dit is vroue wat, ten spyte van ernstige voorbehoude teen en negatiewe ervaring van die Christelike godsdiens, tog weer stadig en versigtig naderkom. Hulle voel solidêr met die kri- 
tiese vroue. Hulle hoop om van die kritiese vroue 'n sinvolle inset ten opsigte van hulle eie lewe te ontvang.

Die duidelike boodskap van die navorsingsresultate in Duitsland is: die getalle van die "tevredenes" groei nie. Die kerk se reaksie is om vroue se kritiese stemme steeds te ignoreer. Die kerk gaan gewoon op 'n paternalistiese wyse voort om aan vroue voor te skryf hoe hulle moet wees en lewe, terwyl alleenlik die manlike perspektief binne die kerk verdiskonteer word. Schulenburg (1993:27) vra of dit die kerk nie sou loon om met die "wegloopvroue" in dialoog te tree en hulle te leer verstaan nie?

Die uitdaging aan die Westers-georiënteerde kerke in Suid-Afrika is of hulle bereid sou wees om te luister selfs vóórdat die groot uittog van vroue ook hier begin. Gegewe die feit dat vroue dwarsoor die wêreld die meerderheid van kerkgangers uitmaak, sou dit waarskynlik as wyse voorsorg van die kerk se kant gesien kan word. "(T)he so-called 'women's question' deals not only with the injury done to the human rights of women, but with the life of the Church, which cannot be whole without the (greater) half of humanity, or more precisely of believers" (Bührig 1993:-10). Kan die kerk dit bekostig om met rigiditeit en paternalisme (soos die reaksie hierbo aantoon) aan te hou?

Die navorsing wat hierbo verdiskonteer is, toon aan dat vroue met 'n kritiese ingesteldheid die kerk se toegang sou kon wees tot dié wat die kerk reeds verlaat het. Dit sou egter impliseer dat daar vir sowel die kritiese vrou as vir die mense wat hulle weer in die kerk inbring, genoegsame ruimte in die kerk moet wees om 'n outentieke lewe voor God te kan lei. Anders sal die kritiese vroue, wat uit lojaliteit steeds in die kerk bly, nie die vrymoedigheid hê om die buitekerklikes weer kerk toe te nooi nie.

Die beperkte en beperkende rolle wat aan vroue toegeken word, die onhoorbaarheid van vroue se stemme en die onsigbaarheid van vroue se bydrae is vasgelê in die kultuur en in kerklike samelewingstrukture. As gevolg van institusionalisering word patriargale norme en strukture as vanselfsprekend aanvaar. Myns insiens is die mees effektiewe wyse om iets konstruktiefs hieraan te probeer doen, nie revolusie nie, maar bewuswording deur middel van 'n bewuswordingsproses. 'n Bewuswording "van onder af" bevraagteken hierdie norme en strukture. So 'n bewuswording "calls for the androcentric viewpoint ('view form above') to be replaced by a 'view from below' - an understanding of experience from the viewpoint of those on the underside 
of history rather than the dominant side" (Unterberger 1990:65). Volgens die bekende teoloog Catharina Halkes (1980: 20) is die doel van so 'n bewuswording om 'n psigososiale proses aan die gang te sit wat daartoe lei dat vroue fundamenteel en radikaal outentieke persone word. Die sosio-ekonomiese faktore wat 'n beduidende rol in die proses speel, sal ondersoek moet word. So 'n bewuswording lei tot die insig dat 'n eensydig manlike sosio-kulturele narratief onaanvaarbaar is in 'n kerk en wêreld wat nie net uit mans bestaan nie. Dit is duidelik dat ' $n$ kontranarratief binne die postmoderne paradigma gehoor begin word.

Dreyer (1998:16) het tereg daarop gewys dat die teologie van 'n geloofsgemeenskap baie belangrik is as die bron van waaruit spiritualiteit en identiteit voortkom. In gesprek met die feministiese teologie word dit duidelik dat vervreemding vir vroue ook op hierdie wesenlike terrein ingetree het. Bührig (1993:55) stel dit so: "As the etymology of the word shows, 'theology' has to do with thinking about God. Women today, both theologians and non-theologians, think a great deal about God inside the Church and outside it. This thinking has led to debates and also to mockery on the part of men." Ek het reeds daarop gewys dat die feministiese teologie probleme daarmee het dat die uitleg en gebruik van die Bybel in die tradisionele teologie vanuit 'n eensydig manlike perspektief geskied (vgl Schüssler Fiorenza 1985; Ruether 1983; Trible 1978; Schneider 1986; Bührig 1993). Die belange onderliggend aan hierdie androsentriese hermeneutiek was doodgewoon verswyg en die resultaat is aangebied as "die norm" en "die teologie". Teenoor patriargale eensydigheid sal daar ten behoewe van vroue se spiritualiteit 'n meer verteenwoordigende en "kontekstuele" teologie ontwikkel moet word. In so 'n teologie kan vroue eindelik volledig as subjekte funksioneer. "Daß zum ersten $\mathrm{Mal}$ in unserer Geschichte Frauen als neue Subjekten von Theologie selber zu Wort kommen, hat weitreichende Folgen, z.B. für die Sprache, für Bilder und Symbolen, mit denen sich Glaube und Theologie ausdrücken" (Schulenburg 1993:30-31; vgl ook Parsons 1997).

Die feministiese teologie wil nie net sisteemkrities omgaan met patriargale strukture van die kerk en teologie nie. Die soeke na 'n lewende spritualiteit staan ook sentraal. Dit is die uitdaging van ons tyd. So 'n moontlikheid vir vroue as die niegeagte ander wat die selfstandige Ander geword het, ook in die teologie, pas volledig in by die postmoderne denke van ons tyd. 


\section{IDENTITEIT}

Theuns Dreyer (1998:11) noem spiritualiteit omvattend 'n "lewensoriëntasie" wat verantwoordelik is vir 'n mens se identiteit. Volgens Roger V Burton en John W M Whiting (1961:89) kan drie tipes identiteit onderskei word: toegekende (attributed), subjektiewe en optatiewe identiteit. Eersgenoemde het te doen met die siening wat 'n ander persoon of groep mense in die gemeenskap van iemand het. Subjektiewe identiteit is dieselfde as selfpersepsie. Optatiewe identiteit is die siening wat iemand graag sou wou hê ander in die gemeenskap van hom of haar moet koester, maar wat om geregverdigde of onaanvaarbare redes nie gebeur nie.

Gesien in die lig dat 'n samelewing vir sigself die goeie wil bevorder, kan beweer word dat sosialisering ten doel het dat 'n persoon se ideale visie vir haar- of homself sal saamval met sowel iemand se selfpersepsie as die identiteit wat aan hom of haar toegeken word. In die manlik gedomineerde modernistiese samelewing bestaan daar egter nie só 'n simmetrie vir vroue nie. Hierdie diskrepansie ontneem vroue van ' $n$ betekenisvolle lewe. Vroue se ideaal vir hulleself kom nie eens ooreen met hulle selfpersepsie nie, omdat sosialiserende institusionalisering by hulle 'n swak selfbeeld skep. Dreyer (1998:11) sê daarom tereg dat spiritualteit as betekeniskern van 'n mens se lewe, te doen met 'n mens se selfpersepsie.

Vanuit 'n vroue-perspektief is Joan Wolski Conn (1986a:3) dit daarmee eens dat spiritualiteit allesomvattend is in die gelowige se lewe:

Christian spirituality involves the human capacity of self-transcending knowledge, love and commitment as it is actualized through the experience of God, in Jesus, the Christ, by the gift of the Spirit. Because God's Spirit comes to us only through experience and symbols inseparable from human community and history, Christian spirituality includes every dimension of human life.

Dit gaan dus nie net oor iets soos byvoorbeeld die innerlike geestelikheid of die ontwikkeling van 'n gebedslewe nie. Spiritualiteit gaan oor die totale menslike bestaan as outentieke lewe voor God. Sy voeg egter by: "Once this view is accepted, however, the problematic nature of women's spiritual development begins to be recognized" (Conn 1986a:3). Indien spiritualiteit gesien word as betekeniskern van 'n mens se lewe wat te doen het met "selfpersepsie", dan is dit juis hier waar die 
probleem ten opsigte van vroue se spiritualiteit aangetref word. Dit het te doen met die vrou se identiteit. As identiteit gevorm word deur internalisering, is dit 'n vraag waarmee vroue in die vorming van hulle identiteit identifiseer en wat dit is wat hulle internaliseer.

Die meeste vroue in die Westerse kultuurkonteks se religieuse sosialisering geskied binne patriargale strukture. Die ontwikkeling van hulle spirituele identiteit word hierdeur gestrem. Kerk en samelewing skryf identiteitsmodelle vir vroue voor wat verhinder dat hulle volledig 'n outonome en eiesoortige spiritualiteit kan ontwikkel (Schulenburg 1993:43). Vanaf die vroegste geskiedenis bepaal mans hoe vroue moet wees, lyk en optree. Die Godsbeelde wat vroue se spiritualiteit vorm, word in kerk en teologie deur mans bepaal. Soos met enige hermeneutiek, is die hermeneutiek hier uiteraard ook nie belangevry nie. Die beelde en interpretasies wat deurgegee word, dien gevestigde magsbelange. Dit dra daartoe by om die status quo te stabiliseer.

Die problematiek van vroue se spiritualiteit, kan veral gesien word in die aspek van volwassenheid (Conn 1986a:3-4). In die dominante kultuur word vroue die moontlikheid tot volwasse spiritualiteit ontneem. Volwassenheid word algemeen beskou as die wegbeweeg van konformisme en voorgeskrewe rolverwagtings na 'n groter mate van outonomie (om self die koers te bepaal, om die self te aanvaar en bevestig, om selfvoorsienend te wees). Vroue-ervaring toon egter dat vroue juis gesosialiseer word om te konformeer met ondergeskikte rolle en dat vroue gestuit word voordat hulle outonomie kan bereik. Beperkte rolle gaan hand aan hand met 'n verengde identiteit (Schulenburg 1993:44). Tot onlangs het die ontwikkelingspsigologie outonomie gesien as differensiasie van ander, onafhanklikheid, om self beheer te neem oor die eie lewe. Met nuwere insigte het daar egter 'n verskuiwing gekom om nie onafhanklikheid nie, maar interafhanklikheid te sien as die doelwit van volwassenheid. Die idee van onafhanklikheid staan direk teenoor vroue se ervaring, waarin relasie en verbondenheid 'n groot rol speel. Vanuit 'n vroue-perspektief sou dit noodsaaklik wees dat ook relasie, verbondenheid en interafhanklikheid, nie alleenlik outonomie nie, 'n noodsaaklike deel van volwassenheid uitmaak. Nie net onafhanklikheid behoort dus as waardevol beskou te word nie, maar ook om te behoort (belonging). Dit is egter nodig om in hierdie verband 'n waarskuwende woord te hoor: 
[Although] women's experience identifies relation as central to reality, it has also flagged the crisis in selfidentity occasioned by the tendency of women to be poorly related to others, that is, to be so concentrated on the needs of others or so dependent on their direction that one's own personal center is diffused. Not just any kind of relationality is to be advocated.

(Johnson 1994:218)

Die Christelike praktyk het eerder bygedra tot die inperking van vroue se volwassenheid as tot die ontwikkeling daarvan. Vroue is geleer om hulleself te verloën en hulle eie behoeftes en belange op te offer ter wille van ander. Waar mans geleer is om selfverloëning te sien in die konteks van die profetiese moed van hulle oortuiging om onregverdige gesag teen te staan, is vroue geleer om alle gesag te sien as Godgegewe. Die uitlewing van eie behoeftes en begeertes moes gesien word as selfsug. Die probleem lê nie as sodanig by die model nie as by hoe dit toegepas word (Conn 1986a:4). Om selfverloëning aan te moedig sonder om te verdiskonteer hoe dit vroue daarvan kan weerhou om 'n outentieke self (outonomie) te ontwikkel, beteken in die praktyk om konformisme met die manlik voorgeskrewe rolle te bevorder.

Vroue word gesosialiseer om ander se behoeftes raak te sien en daarop te reageer. Daarom onderdruk hulle hulle eie behoeftes in so 'n mate dat hulle dit later moeilik of selfs onmoontlik vind om te weet wat daardie behoeftes is. Vanweë hierdie sosialisering durf vroue geen diepgesetelde behoefte aan outonomie erken nie, want, soos gekondisioneer, stel hulle dit onmiddellik gelyk gestel aan selfsug.

Vroue word gesosialiseer om begeerlike objekte te wees. Hulle voorkoms en denke moet van so 'n aard wees dat dit aanvaarbaar is, veral vir mans. Om te lewe "vir ander", is wat van vroue verwag word. Dit beteken in wese dat vroue totaal opgaan in ' $n$ ander se identiteit, behoeftes en belange. Hierdie sosiale verwagting wat aan vroue gestel word, hou 'n wesenlike gevaar in vir vroue se eie identiteit. Die gebrek aan 'n goedomlynde, gevestigde eie identiteit vernietig die moontlikheid tot outentieke lewe. 'n Vrou word gekondisioneer dat haar lewe eers waarde kry wanneer iemand ('n manlike persoon) haar "gevind" het en haar lewe in syne kan opgaan. Aan 'n vrou op haar eie ken die dominante sosio-kulturele narratief nie veel waarde toe nie. 
Vroue word gestereotipeer as "van nature" opofferend en toegewyd aan ander. Dit word beskou as deel van wie vroue is - as deel van hulle identiteit. Die problematiese konsekwensies van hierdie kondisionering word nie in ag geneem nie. Die navorsing van Jane Loevinger (1979; vgl Conn 1986b:11) spel van hierdie konsekwensies uit. Dit toon aan dat "vroulike" gedrag wat aangeprys word as "goed" en "aanvaarbaar", in wese simptomaties is van 'n ernstige graad van onvolwassenheid. Een van die simptome wat algemeen onder vroue voorkom, is 'n gebrek aan eiewaarde (vgl Sanford \& Donovan 1985). Dit veroorsaak emosionele afhanklikheid wat weer daartoe lei dat vroue geweldig veeleisend word in hulle behoefte aan blyke van waardering en aanvaarding. Verder lei dit tot koverte manipulasie, gemaakte hulpeloosheid en 'n vermyding van konfliksituasies. Vrede ten alle koste het 'n duur prys: woede word onderdruk en dit kan lei tot depressie. Gedrag wat, aan die ander kant, nie deur die dominante narratief aangeprys word nie, wat beskou word as selfsugtig en dus "onvolwasse" vir vroue kan juis optrede wees wat spreek van 'n sterker eiewaarde, groter emosionele onafhanklikheid, minder veeleisende en manipulerende gedrag in verhoudings.

Die hele saak kom neer op wat in Engels genoem word a double bind: vroue word geprys as "goed" juis wanneer hulle nog nie 'n outentieke self ontwikkel het nie en afgemaak as 'n "slegte vrou en ma" wanneer hulle begin om gedrag te toon wat wel dui op die ontwikkeling van 'n eie identiteit en 'n outentieke self. 'n Outentieke self is 'n noodsaaklike voorvereiste voordat 'n persoon in 'n volwasse, liefdevolle relasie die self aan 'n ander (God ingesluit) kan gee. Wie nie 'n self het nie, het ook niks om te gee nie. Die gevolge vir vroue kan soos volg opgesom word:

Women conditioned to role conformity, to self-doubt, and to dependency may find it quite difficult to get in touch with their own deepest desires or to be peacefully present to a God who respects their adult freedom and calls them friend not servant. Freedom and friendship involve making significant decisions and owning up to the consequences; they involve risk and struggle with ambiguity which insecure women find very difficult, if not impossible, to face.

(Conn 1986b:12) 
Vanweë die beperkte voorgeskrewe rolle vir vroue, kan met reg gesê word: "(W)omen have not experienced their own experience" (Christ 1980:5). 'n Spiritualiteit wat ontwikkel het uit 'n beperkte en dikwels negatiewe ervaring, kan onmoontlik dien as voldoende onderbou vir 'n volle, outentieke lewe voor God (vgl Unterberger 1990:65). Spiritualiteit is onvermydelik "religieus selfstandige denke en handeling". Selfstandige denke en handeling verg 'n gevestigde identiteit, 'n ontwikkelde volwassenheid en 'n sterk gevoel van eiewaarde. Waar hierdie dinge ontbreek, het mense nie die moed of innerlike krag om verantwoordelikheid te aanvaar vir die konsekwensies van hulle denke, optrede en keuses nie. Spiritualiteit rig die aandag van vroue op die keuses wat hulle as selfstandige persone maak. Hierdie keuses bepaal die kwaliteit van hulle persoonlike lewe en lewe in groepsverband (Schulenburg 1993:36, 38; vgl ook Schneider 1986). Outentieke lewe voor God kan nie anders as om ' $n$ kwaliteitlewe te veronderstel nie.

Hierbo is genoem dat spiritualiteit te doen het met identiteit en selfpersepsie, asook dat identiteitvorming 'n proses van sosialisering is. Sosialisering vind binne 'n gemeenskap plaas - in die konteks van spiritualiteit is dit die geloofsgemeenskap. Die geloofgemeenskap het die taak om 'n milieu vir sosialisering te skep wat gesonde identiteitvorming tot gevolg kan hê. Die Christelike godsdiens glo dat die Gods- en mensbeelde wat die kerk deurgee aan mense, verlossend en bevrydend inwerk op hulle lewe en hulle bring tot 'n outentieke bestaan in God se teenwoordigheid. Dit meen verder dat geloofsimbole help om mense "tot spreke te bring". Die uitwerking hiervan bevorder ' $n$ gesonde identiteitvorming. Die vraag is egter of hierdie aanspraak in vroue se ervaring en lewenswerklikheid weerspieël word. Word vroue tot spreke gebring? Word vroue se identiteitvorming bevorder en vroue-ervaring ernstig opgeneem? Bied die kerk die ruimte vir vroue om in hulle spiritualiteit te ontluik tot selfstandig denkende en handelende persone (Schulenburg 1993:41)?

Ek het hierbo aangetoon dat vroue vir wie 'n menswaardige selfpersepsie en 'n eie identiteit belangrik is, vervreemding kan beleef van 'n geloofsgemeenskap wat hulle wil sosialiseer tot nie-identiteit. Vroue binne die teologiese opleiding waar die vorming van die spiritualiteit en identiteit van die voornemende predikant moet plaasvind, het niemand om mee te identifiseer nie, omdat daar nie vroue as dosente aangestel is nie. Die negatiewe, beperkende en onmenswaardige boodskappe oor vrouwees wat deur kultuur en kerk oorgedra en deur vroue geïnternaliseer word, het 'n skadelike effek op die vorming van identiteit. Dit word noodsaaklik om bewus te word van 
die uitwerking van religieuse sosialisering. Met bewuswording kom 'n veranderende krag (kyk Schulenburg 1993:44).

Dreyer (1998:14) het aangetoon dat daar altyd krities gesoek moet word na vorme wat in elke nuwe tyd uitdrukking kan gee aan die gemeenskap se spiritualiteit en identiteit. Indien die wyse waarop die geloofsgemeenskap uitdrukking gee aan spiritualiteit en identiteit vervreemdend inwerk op 'n groot gedeelte van die lede en skadelik is vir hulle religieuse identiteitvorming, het die tyd gekom om krities te soek na nuwe vorme om daaraan uitdrukking te gee. Dreyer (1998:7) het ook daarop gewys dat verskillende spiritualiteite verrykend op mekaar kan inwerk sonder dat geloofsgemeenskappe die gevaar loop om hulle identiteit te verloor. Myns insiens sou 'n spiritualiteit wat positief inwerk op die identiteitvorming van vroue nie die kerk se identiteit bedreig nie, maar juis verrykend daarop kan inwerk. As die geloofsgemeenskap daarin slaag om 'n positiewe milieu te bied vir die proses van identiteitvorming van al die lede wat tot die gemeenskap behoort, sal dit nie skade doen nie. Inteendeel, die geloofsgemeenskap sal intern soveel sterker staan en ekstern veel meer geloofwaardig voorkom.

Vervolgens wil ek aandag gee aan die bydrae wat 'n spiritualiteit vanuit die perspektief van vroue wat ook graag as subjekte wil funksioneer, tot die geloofsgemeenskap kan maak. Beskrywings van Gereformeerde spiritualiteit gaan meesal gepaard met dualistiese en polariserende denke en taalgebruik (die taal van die moderne era). Byvoorbeeld: dit gaan primêr om God, nie om die mens nie. God neem al die inisiatief waarteenoor die radikaal verdorwe mens niks het om by te dra nie. Die fokuspunt is God se genade en nie die mens se geloof of bekering nie. 'n Verdere kenmerk is die beheer en kontrole van die rede (nog 'n aspek van moderne denke). So byvoorbeeld word die belydenisskrifte en dogmas (soos die "uitverkiesingsleer") voorgehou as raamwerk, sodat die spiritualiteit van lidmate nie daarbuite verdwaal nie. Woorde is belangrik, want in Gereformeerde spiritualiteit is daar "geen sprake van 'n woordelose omgang met en selfs opgaan in God nie" (Dreyer 1998:8). 'n Protestantse vrou se belewing van haar woordbelaste tradisie klink so: "Worte. Nur Worte. Worte davon. Worte darüber. Aber nie ist es lebendig. Nie geschieht es, nie wirklich" (in Schulenburg 1993:51).

As Reformatoriese teoloog is die voorrang wat die Skrif in die teologie en in die kerk inneem, vir my vanselfsprekend. Die verhouding met God is as ontmoetingsgebeure ook 'n woordgebeure. Geloof in God moet egter nie met geloof in die Skrif 
verwar nie. Die Skrif is 'n versameling getuienisse van geloof. Meditasie en kontemplasie oor die kwaliteit van hierdie getuienisse bring 'n transendering van die self mee wanneer die tegemoet tree van God na die mens toe self ervaar word. In hierdie sin van die woord is die (meerduidige) Skrif vir my, ook wat spiritualiteit betref, die klassieke model, die sentrum van oriëntasie oor wat geloof as outentieke lewe is. Geloof is die lewe wat moontlik gemaak is deur God se kom na die mense toe in en deur die woorde en dade van Jesus van Nasaret. Geloof is 'n bron van vreugde, want die gelowige se direkte en onbemiddelende toegang tot God is nou moontlik.

In Gereformeerde spiritualteit word die vreugde egter gedemp deur die swaarwigtige klem wat op sonde en verlorenheid gelê word. Wanneer Dreyer die aard van Gereformeerde spiritualteit uiteen sit, is sy gebruik van die woordjie "egter" dus gepas as die saak van vreugde aan die orde kom: "Die Gereformeerde spiritualiteit is egter nie sonder vreugde nie" (Dreyer 1998:9; my beklemtoning). Hier word die vreugde gestel as teenoor die gelowige se bewussyn van "gebrokenheid en onvolmaaktheid". Teenoor geestelike ekshibisionisme word gepleit vir beskeidenheid. Vir enigiemand uit die Reformatoriese tradisie is daar sekerlik nie fout te vind met die meeste beginsels onderliggend aan bogenoemde beskrywing van Gereformeerde spiritualiteit nie. Gereformeerde denke kom egter voort uit die moderne paradigma. 'n Vroue-perspektief wat erns maak met postmoderniteit sou klem lê op integrasie, heelheid, relasie met God in plaas van polarisering teenoor God. Daarom bepleit ek dat vreugde gesien met word as iets vanweë, in plaas van 'n vreugde ten spyte van.

Oor so 'n spiritualiteit sê Unterberger (1990:86): "The intense desire to make connections instead of splitting and separating one thing from another is evident ... (R)elationality and connection become paramount values." Die Nederlandse sistematiese teoloog, A van de Beek (1996:5), stel dit so: "Heelheid is mijns inziens een woord dat voor spiritualiteit wezenlijk is ... De Geest maakt de gebrokenheid van het bestaan weer heel. Elementen uit ons bestaan die uiteenspatten en die we niet meer kunnen integreren, worden in het waarachtige leven verbonden."

\section{GEVOLGTREKKING}

'n Vroueperspektief ten opsigte van spiritualiteit as deurleefde religieuse identiteit gaan om God wat in Jesus mense vry maak om te lewe. Dit sien spiritualitet nie as 'n 
abstrakte, lewensvreemde konsep nie, maar as eksistensiële, wesenlike momente in die voortgaande beweging van egte lewe. Identiteit is dan nie die statiese "kern van menswees" met "stabiliteit" en "kontinuïteit" as die twee groot eienskappe nie. Hierdie rigiede siening gee nie ruimte vir die prosesmatige, die besondere, die emosionele, die onsekere nie. Identiteit vanuit 'n vroueperspektief word eerder gesien as 'n proses van ontvouing - 'n proses waarin die mens oop is vir die religieuse dimensie van die lewe (kyk Schulenbrug 1993:39-41).

Religieuse ervaring hou die belofte in om die self te transendeer. Wat getransendeer word, is die verbondenheid met die alledaagse, met die liggaam. Daardie verbondenheid hoef dus nie ontken te word deur vergeesteliking, dogmatisering of intellektualisering nie. Juis die beliggaamde menswees en die verbondenheid aan ander en aan hierdie wêreld is die noodwendige beginpunt van die transenderingsproses. Indien nie, wat moet dan getransendeer te word? Spiritualiteit vanuit 'n vroueperspektief ondersteun die gewone, alledaagse, aardse lewe en word die bevrydende en inspirerende impuls vir die proses van om waarlik mens te wees. Spiritualiteit as "deurleefde religieuse identiteit" gaan dan oor outentieke lewe voor God. "In ihr [die Spiritualität] kommt das Verlangen von Menschen nach Leben-digkeit und Ganzheitlichkeit zum Ausdruck. Sie verdichtet sich in den Räumen, wo religiöse Erfahrungen als authentische Lebensäußerungeñ zur Sprache gebracht werden ..." (Schulenburg 1993:41). So 'n spiritualiteit het heelheid, omvattende wel-syn en outentieke lewe voor God in die oog. Heil word nie geskei van heling, of die geestelike van die alledaagse en ligaamlike nie. Die mens word gesien as 'n geïntegreerde wese wat 'n geïntegreerde (outentieke) lewe voor God lei. So 'n spiritualiteit is terselfdertyd, ter wille van die totale welsyn van vroue ook “... interested in restoring the dignity and power of women, working for women's well-being ... on a variety of fronts" (Unterberger 1990:90). Vir vroue is spiritualiteit om verbande te lê tussen wat hulle glo en die alledaagse dinge van hulle bestaan. Dit gaan dus, soos Tatman (1998) sê, om spirituele heelheid in plaas van gespletenheid.

\section{Literatuurverwysings}

Adam, A K M 1995. What is postmodern biblical criticism? Minneapolis, MN: Fortress. (Guides to Biblical Scholarship.) 
Bons-Storm, $\mathrm{R}$ 1996. The incredible woman: Listening to women's silences in pastoral care and counseling. Foreword by P D Couture. Nashville, TN: Abingdon Press.

Bührig, M 1993. Woman invisible: A personal odyssey in Christian feminism. Valley Forge, PA: Trinity Press International.

Burton, R V \& Whiting, J W M 1961. The absent father and cross-sex identity. Merill-Palmer Quarterly 7, 85-95.

Christ, C 1980. Diving deep and surfacing: Women writers on a spiritual quest. Boston, MA: Beacon Press.

Conn, J W 1986a. Introduction, in Conn, J W (ed), Women's spirituality: Resources for Christian development, 1-8. New York, NY: Paulist.

- 1986b. Women's spirituality: Restriction and reconstruction, in Conn, J W (ed), Women's Spirituality: Resources for Christian development, 9-30. New York, NY: Paulist Press.

Dreyer, T F J 1998. Spiritualiteit, identiteit en die etos van die Hervormde Kerk. HTS 54(1\&2), 289-314.

Halkes, C J M 1980. Gott hat nicht nur starke Söhne: Grundzüge einer feministischen Theologie. Gütersloh: Gütersloher Verlag.

Johnson, E A 1994. She who is: The mystery of God in feminist theological discourse. New York, NY: Crossroad.

Loevinger, J 1979. Stages of ego development, in Mosher, R L (ed), Adolescents' Development and education, 110-123.

Parsons, S F 1997. The dilemma of difference: A feminist theological exploration. Feminist Theology 14, 51-72.

Rossouw, G J 1993. Theology in a postmodern culture: Ten challenges. HTS 49(4), 894-907.

Ruether, R R 1983. Sexism and God-talk: Toward a feminist theology. Boston, MA: Beacon.

Sanford, L T \& Donovan, M E 1985. Women and self-esteem. New York, NY: Penguin.

Schneider, S M 1986. The effects of women's experience on their spirituality, in Conn, J W (ed), Women's spirituality. New York, NY: Paulist Press. 
Schulenburg, A 1993. Feministische spiritualität: Exodus in eine befreiende Kirche? Stuttgart: Kohlhammer.

Schüssler Fiorenza, E 1985. In memory of her: A feminist theological reconstruction of Christian origins. New York, NY: Crossroad.

Tatman, L 1998. The yearning to be whole-enough or to feel something, not nothing: A feminist theological consideration of self-mutilation as an act of atonement. Feminist Theology 17, 24-38.

Trible, P 1978. God and the rhetoric of sexuality. Philadelphia, PA: Fortress. (Overtures to Biblical Theology.)

Unterberger, G L 1990. Through the lens of feminist psychology and feminist theology: A theoretical model for pastoral counseling. A Doctor of Philosophy dissertation, School of Theology at Claremont.

Van de Beek, A 1996. Spiritualiteit een must voor theologen? Gereformeerd Theologisch Tijdschrift 96(1), 3-10.

Von Wartenberg-Potter, B 1987. We will not hang our harps on the willows: Engagement and spirituality. Geneva: WWC Publications. 